\title{
Bacterial activity in the sea-surface microlayer: in situ investigations in the Baltic Sea and the influence of sampling devices
}

\author{
Christian Stolle*, Klaus Nagel, Matthias Labrenz, Klaus Jürgens \\ Leibniz-Institute for Baltic Sea Research (IOW), Seestrasse 15, 18119 Rostock, Germany
}

\begin{abstract}
The sea-surface microlayer (SML) is considered to be an 'extreme' environment. However, it is still unclear how bacteria that inhabit the SML (bacterioneuston) react to conditions within this interface. This deficiency is partly caused by the difficulty in obtaining representative samples. Our aim was to examine different sampling devices and characterize bacterioneuston activity in the Baltic Sea. Initial in situ studies revealed a decreased incorporation of ${ }^{3} \mathrm{H}$-thymidine $\left({ }^{3} \mathrm{H}\right.$-TdR) by up to $90 \%$ in both glass-plate and metal-screen samples compared to the underlying bulk water. However, a series of tank experiments showed selective inhibition of bacterial productivity with either of these sampling devices, although bacterial cell counts and community composition were unaltered. The inhibition introduced by the glass plate could not be nullified by different cleaning treatments, but by the wiping technique used to scrape off the sample. Even with this modified, unbiased glassplate technique, ${ }^{3} \mathrm{H}$-TdR incorporation of the bacterioneuston was still reduced by 50 to $80 \%$ compared to that in the underlying water, whereas the abundance of 5-cyano-2,3-ditolyl tetrazolium chloride (CTC)-positive cells was not affected. Our in situ study thus revealed that in the Baltic Sea the presence of a pronounced bacterioneuston community different from that in the underlying water is unlikely. Reduced bacterial activities within the SML support the concept of a demanding habitat. Additionally, this study emphasizes the need to carefully evaluate the sampling devices used when measuring bacterial parameters. Furthermore, it supports the view that caution is required in comparisons of results from different studies.
\end{abstract}

KEY WORDS: Sea-surface microlayer $\cdot$ Bacterioneuston $\cdot$ Sampling devices $\cdot$ Bacterial activity Resale or republication not permitted without written consent of the publisher

\section{INTRODUCTION}

The air-water interface spans $71 \%$ of the Earth's surface. This layer, which constitutes the boundary between the atmosphere and underlying water bodies, is crossed by fluxes of mass and energy. Several models describe the organization of the interface as a more or less stratified surface film (Norkrans 1980, Sieburth 1983, Falkowska 1999b), with the top layer referred to as the sea-surface microlayer (SML). The SML is considered to be an 'extreme' environment because of its physicochemical properties relative to those of the underlying water (Maki 1993). According to this view, the bacterioneuston (i.e. bacteria within the SML) is exposed to intense UV-radiation (Maki 2002) as well as to the accumulation of pollutants (Wurl \& Obbard
2004) and heavy metals (Hardy \& Cleary 1992). In contrast, the accumulation of organic and inorganic substrates in the SML may be beneficial to its microbial communities (Williams 1986).

The physical, chemical, and biological properties in a variety of surface films, including those of different marine and limnic habitats, have been investigated in several studies. Earlier studies suggested that the SML is enriched in several chemical and biological compounds (Sieburth et al. 1976, Hardy 1982). However, conflicting results, especially those regarding bacterioneuston parameters, can be found in the literature. Cell counts of bacteria in the SML have been shown to be enriched in several habitats (Kuznetsova \& Lee 2002, Joux et al. 2006), but similar abundances of bacterioneuston and bacterioplankton have also been 
reported (Hermansson et al. 1987, Reinthaler et al. 2008). The enzymatic activity of the bacterioneuston has been found to be generally enhanced compared to that of bacterioplankton (Münster et al. 1997, Kuznetsova \& Lee 2001), as opposed to bacterial productivity in SML samples, which was found to be decreased or highly variable compared to bulk measurements (Obernosterer et al. 2008, Reinthaler et al. 2008). Additionally, the diversity of bacterial and archaeal communities in the SML, based on 16S rDNA and functional gene analysis, has been shown to differ from that of the underlying water (Franklin et al. 2005, Auguet \& Casamayor 2008, Cunliffe et al. 2008). However, such differences have been found to be highly dynamic, implying that the presence of a different bacterial community in the SML is not a general phenomenon (Agogué et al. 2005).

Consequently, there is no consistent view regarding the structure and function of the bacterioneuston or whether a particularly adapted bacterial community exists in the SML. This inconsistency can be explained by several reasons. (1) The SML undergoes highly dynamic spatial and temporal changes. These include longer time scales (e.g. seasonality) as well as shorter time scales (e.g. disintegration of surface slicks). Accordingly, bacterioneuston community structure at a single sampling site has been found to differ substantially from one day to the next (Agogué et al. 2005).

(2) The predominant problem of studying the SML is obtaining proper samples (Maki 1993). Investigation of an undisturbed SML, i.e. one in which the native surface-to-volume ratio is maintained, is preferable (Hermansson \& Dahlbaeck 1983); however, since most characterizations depend on obtaining larger water volumes, a change in the SML surface-to-volume ratio is generally unavoidable. Ideally, SML samples should be diluted as little as possible with bulk water. Current sampling devices obtain SML layers of different thickness depending on their operating mode. The thinner a collected SML sample is, the more selective the respective sampling device is thought to be. Therefore, sampling of the SML must take the following into account (Garrett \& Duce 1980, Huehnerfuss 1981): (1) thickness of the SML sample, (2) selectivity of the sampling device, (3) sampling volume and time, and (4) handling of the sampling device. Additionally, other factors such as wind speed, water temperature, and wave states at the time of collection have been reported to influence the thickness of SML samples (Carlson 1982, Falkowska 1999a).

Glass-plate (GP), rotating-drum (RD), and metalscreen (MS) sampling devices are the most widely used in studies of the SML. Both the GP and the RD function as solid adsorbers (Harvey 1966, Harvey \& Burzell 1972). The samples collected with these devices are therefore much thinner (22 to $100 \mu \mathrm{m}$ ) than samples taken with the MS (150 to $440 \mu \mathrm{m})$, which traps the water within its mesh by surface tension forces (Garrett 1965). These inherent differences in layer thickness imply the collection of different water samples. Indeed, laboratory experiments have shown different recovery rates of artificial surface films by GP and MS devices, with the efficiency of either one dependent upon the film materials used (Hatcher \& Parker 1974, van Vleet \& Williams 1980). A recent and very extensive study investigated the possible bias of different samplers (Agogué et al. 2004). The authors concluded that neither the GP nor the nylon screen used in their study influenced the characterisation of the investigated biological parameters. However, as the authors pointed out, there has been no further comparative study which evaluates the possible selective effects of these sampling devices on biological constituents of the SML.

In the present study, we sampled the SML using GP, MS and RD sampling devices in order to examine bacterioneuston abundance and activity in the southern Baltic Sea. We then conducted tank experiments to evaluate potential bias introduced by the GP and MS to determine an appropriate sampling technique. Finally, SML samples were taken with a modified version of the GP device in the southern and central Baltic Sea, yielding new, unbiased measurements of bacterioneuston activity.

\section{MATERIALS AND METHODS}

Sampling site. Sampling was conducted in the southern Baltic Sea, offshore of Warnemuende, from July to September 2006 and June to August 2007. To avoid the effects of pollutants, high nutrients loads, and the plume of the Warnow River, sampling sites opposite the wind direction were chosen. Additionally, SML samples were obtained in the central Baltic Sea (Gotland basin) in July 2007. All samples were taken under calm wind conditions (<4 Beaufort), usually between 07:00 and 09:00 h (UTC).

SML sampling. SML samples were taken with a Harvey GP and a Garrett MS from a zodiac and an RD placed on a catamaran. Sampling with the GP and the MS was usually conducted windward to avoid contamination from the zodiac. The MS had an overall area of $375 \mathrm{~cm}^{2}$ and consisted of wire with a diameter of $0.17 \mathrm{~mm}$ and $1 \mathrm{~mm}^{2}$ mesh, forming an open-space area (i.e. effective collection area) of $281 \mathrm{~cm}^{2}$. During sampling, the MS was placed horizontally on the sea surface, lifted carefully, and then orientated vertically to allow samples to drain into sterilized glass bottles. 
The GP had dimensions of $500 \times 250 \times 4 \mathrm{~mm}$, with an effective sampling area of about $2000 \mathrm{~cm}^{2}$ (including both sides of the plate). Samples were collected by vertically inserting the GP into the water column and withdrawing it the same way, with a sampling velocity of about $10 \mathrm{~cm} \mathrm{~s}^{-1}$. The samples were scraped off the GP with either a manual hand-wiper or framed wipers and collected in sterilized glass bottles. In both cases, the wipers consisted of $0.4 \mathrm{~mm}$-thick Teflon blades. Both the MS and the GP were cleaned with Milli-Q water and ethanol (70\%) and intensively rinsed with seawater before being used.

The RD (Harvey 1966), which consists of a ceramiccoated drum with a sampling area of $5750 \mathrm{~cm}^{2}$, was placed on a catamaran. The device is battery-driven and was operated at constant speed against the wind direction. Comparable to the GP, the samples were scraped off using a Teflon wiper and then pumped backwards for collection into sterilized glass bottles.

Bulk water was collected from a depth of $1 \mathrm{~m}$ with a 2 1 glass collection tube and the ends were closed by a drop-weight mechanism. Results from the SML samples were compared to those from bulk-water measurements and are expressed as enrichment factors (EF) as defined in the following equation: $\mathrm{EF}=$ $[x]_{\mu} /[x]_{b}$, where $[x]$ is the concentration of a given parameter in the SML $(\mu)$ or bulk water (b) (Hardy et al. 1997). The thickness of the SML layer was determined by the sample volume per area of the sampling device.

Tank experiments. To evaluate possible selectivity of the MS and GP sampling devices, tank experiments were carried out using $60 \mathrm{l}$ of seawater filled in a plastic container. For this purpose, surface water was obtained in the morning from the pier in Warnemuende. Experiments started immediately upon the return to the institute, i.e. usually $<1 \mathrm{~h}$ later. To avoid formation of a sea-surface film, the water was stirred prior to each sampling. This stirring most likely does not inhibit formation of a microlayer, as the reformation of organic surface films was described to be very fast (Hardy 1982). However, the water was homogenized to prevent the formation of a thickening surface film during the experiment. Reference water was obtained with a glass bottle that was opened in the middle of the tank. Three independent experiments were conducted to evaluate the MS and the GP in which the water was sampled once, twice and 3 times in the first, second and third experiment, respectively ( $\mathrm{n}=6$ ). SML thicknesses of the MS and GP samples were $223 \pm 62$ and $29 \pm 5 \mu \mathrm{m}$, respectively. Additionally, 2 experiments were conducted to test the effect of cleaning the GP as well as a new wiping device for the GP. In each of these experiments, the water was sampled 3 times $(n=3)$. SML thicknesses in these experiments were found to be higher (56 \pm 4 and $36 \pm 5 \mu \mathrm{m})$ than in the first experiments, but neither the cleaning procedures nor the wiping device had an influence on the thickness compared to the respective control GP. In all experiments, 300 to $500 \mathrm{ml}$ of water was collected with each sampling device for subsequent analysis. The water temperature in the tank did not change throughout the experiments (data not shown).

Bacterial cell counts. Bacteria were counted with a flow cytometer. Samples of $4 \mathrm{ml}$ were incubated with $400 \mu \mathrm{l}$ paraformaldehyde (1\% final concentration)/ glutaraldehyde $(0.05 \%$ final concentration) in the dark for $1 \mathrm{~h}$ at $5^{\circ} \mathrm{C}$. After fixation, the samples were frozen in liquid nitrogen and stored at $-80^{\circ} \mathrm{C}$. Heterotrophic bacteria were stained with SYBR Green $(2.5 \mu \mathrm{M}$ final concentration, Molecular Probes) for $30 \mathrm{~min}$ in the dark. Cells were counted using a Becton \& Dickinson FACScalibur equipped with a laser emitting at $488 \mathrm{~nm}$

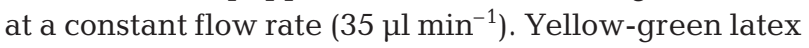
beads $(0.5 \mu \mathrm{m}$, Polysciences) were used as an internal standard. Bacteria were detected by their signature in a plot of side scatter (SSC) versus green fluorescence (FL1).

Enumeration of metabolically active (CTC-positive) cells. From each sample, $900 \mu \mathrm{l}$ was incubated with $100 \mu$ of a 5-cyano-2,3-ditolyl tetrazolium chloride (CTC, Polysciences) solution (4 mM final concentration) in the dark at the in situ temperature for 1 to $3 \mathrm{~h}$. CTC uptake was stopped by fixation of the samples with paraformaldehyde (1\% final concentration)/ glutaraldehyde $(0.05 \%$ final concentration) in the dark for $10 \mathrm{~min}$ at $5^{\circ} \mathrm{C}$. The samples were then frozen in liquid nitrogen and stored at $-80^{\circ} \mathrm{C}$. Cells were counted with a flow cytometer as described in 'Bacterial cell counts', except that the beads for the internal standard were $1 \mu \mathrm{m}$ in size and cells were detected by their signature in a plot of orange fluorescence (FL2) versus red fluorescence (FL3).

Bacterial productivity. The incorporation of $10 \mathrm{nM}$ ${ }^{3} \mathrm{H}$-methyl-thymidine $\quad\left({ }^{3} \mathrm{H}-\mathrm{TdR}\right) \quad\left(60.1 \mathrm{Ci} \mathrm{mmol}^{-1}\right.$, Moravek Biochemicals) was measured to determine the heterotrophic bacterial productivity in $5 \mathrm{ml}$ water samples. Additionally, $5 \mathrm{ml}$ samples from the tank experiments were dual-labeled with $10 \mathrm{nM}{ }^{3} \mathrm{H}-\mathrm{TdR}$ and $50 \mathrm{nM}^{14} \mathrm{C}$-leucine $\left(261 \mathrm{mCi} \mathrm{mmol}^{-1}\right.$, Movarek Biochemicals) and then extracted with cold trichloroacetic acid (TCA) according to the method of Chin-Leo \& Kirchman (1988). Triplicate samples were incubated for at least $1 \mathrm{~h}$ at the in situ temperature in the dark. Incorporation was stopped by fixing the cells with formaldehyde $(10 \% \mathrm{v} / \mathrm{w})$ in the dark overnight at $5^{\circ} \mathrm{C}$. A fourth sample, serving as a blank, was fixed for at least $10 \mathrm{~min}$ prior to the addition of the radioactively labeled substrates. In situ samples collected in 2006 were filtered on $0.22 \mu \mathrm{m}$ nitrate-cellulose membranes. Samples from the tank experiments and those ob- 
tained in situ in 2007 were filtered on $0.22 \mu \mathrm{m}$ polycarbonate filters (Millipore), as these filters yielded less background signals. Four milliliters of scintillation cocktail was added to the filters after which the incorporated substrates were counted in a scintillation counter (Packard).

DNA extraction. Water samples were filtered on $3 \mu \mathrm{m}$ Isopore filters (Millipore), which are presumed to retain the particle-attached fraction. The flow-through (i.e. the non-attached fraction) was then filtered on $0.22 \mu \mathrm{m}$ Isopore filters (Millipore). All filters were rapidly frozen in liquid nitrogen and then stored at $-80^{\circ} \mathrm{C}$. DNA from frozen filters was extracted using a phenol-chloroform-extraction method, according to Weinbauer et al. (2002). DNA in the extracts was quantified spectrophotometrically using a NanoDrop ND1000 (NanoDrop Technologies).

Fingerprint analysis. The 16S rDNA fingerprints of the bacterial community were analyzed based on single-strand-conformation polymorphism (SSCP) or terminal restriction fragment length polymorphism ( $\mathrm{T}$ RFLP) analysis. For the former, DNA extracts were PCR-amplified using primers Com1 (5'CAG CAG CCG CGG TAA TAC3') and Com2-Ph (5'CCG TCA ATT CCT TTG AGT TT3') (Schwieger \& Tebbe 1998), which amplify Escherichia coli 16S rDNA positions 519 to 926, and following a protocol described elsewhere (Labrenz et al. 2007). Single-stranded DNA was generated and purified and the SSCP analysis carried out as described in Schwieger \& Tebbe (1998). Cluster analysis of band patterns was done with GelCompare II (Applied Maths NV). Comparisons of the samples were based on the absence or presence of individual bands (Jaccard coefficient) or on their densiometric profile (Pearson correlation).

T-RFLP fingerprints were done with PCR amplicons under the conditions described by Lehours et al. (2005), with $1 \mathrm{ng}$ of template DNA and the primers $27 \mathrm{f}$ (5'AGA GTT TGA TCC TGG CTC AG3') and 907r (5'CCG TCA ATT CMT TTR AGT TT3'), according to Liu et al. (1997). Primer $27 \mathrm{f}$ was 5 '-labeled with 6-carboxyfluorescin (FAM). PCR products were purified using a Nucleospin®Extract II kit (Macherey \& Nagel). Sixty nanograms of purified amplicons were digested overnight with MspI (Fermentas) following the manufacturer's instructions. The terminal restriction fragments were cleaned, separated, and analyzed as described in Hannig et al. (2006). Comparisons of the different samples followed the iterative normalization procedure as introduced by Dunbar et al. (2001).

Analysis of total organic carbon and total nitrogen. Ten milliliter water samples were sealed in $\mathrm{HCl}$ precleaned and precombusted $\left(450^{\circ} \mathrm{C}, 6 \mathrm{~h}\right)$ glass ampoules using a portable propane torch. The sealed ampoules were quickly frozen, without the addition of preservatives, and stored at $-20^{\circ} \mathrm{C}$ until analysis in the laboratory.

Total organic carbon (TOC) and total nitrogen (TN) were quantified using a high-temperature combustion method, carried out in the presence of a Pt-catalyst on a Shimadzu TOC-V analyzer supplemented with a Shimadzu TNM-1 nitrogen detector and a Shimadzu ASI$\mathrm{V}$ autosampler. This system allows simultaneous determination of TOC and TN in the same sample. The temperature of the catalyst was kept at $680^{\circ} \mathrm{C}$ and carbon-free air produced by a Whatman gas generator was used as carrier gas (flow rate $150 \mathrm{ml} \mathrm{min}^{-1}$ ). Acetanilide was used to calibrate (4-point calibration) TOC and TN measurements.

Prior to their analysis, the samples were acidified with $2 \mathrm{~N} \mathrm{HCl}$ (suprapure grade) to a final $\mathrm{pH}$ of 2 . Concentrations of TOC and TN were calculated based on 4 injections of the sample (injection volume $75 \mu \mathrm{l}$ ). All samples were run in duplicate. The reliability of each analytical run was checked using external reference material in a seawater matrix for TOC and TN and using reference material for measurement of the blank. The reference material was obtained from the Consensus Reference Materials program (D. Hansell, University of Miami). Measured concentrations of TOC

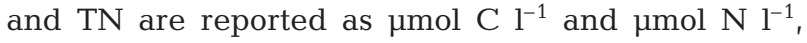
respectively.

Statistical analysis. The Kolmogorov-Smirnov test was applied to determine the hypothetical normal distribution of the samples, which was true for all measurements. To examine the equality of means between the SML samples and the underlying water as well between the samples from the control experiment, the $t$-test for independent samples with a confidence level of $95 \%$ was chosen; $\mathrm{p}<0.05$ indicated that the means of the samples were significantly different.

Spearman's rank correlation was applied to test the association between bacterial ${ }^{3} \mathrm{H}-\mathrm{TdR}$ incorporation and CTC-positive cells and between these parameters and the wind speed.

\section{RESULTS}

\section{SML samples 2006}

Coastal SML samples were obtained from the southern Baltic Sea in the summer of 2006 using GP and MS sampling devices. GP samples, from 9 different stations, were $28 \pm 3 \mu \mathrm{m}$ thick compared to $267 \pm 43 \mu \mathrm{m}$ for MS samples, taken from 12 stations (data not shown). The total bacterial cell counts of SML samples from the GP and MS sampling devices did not differ from those of the underlying bulk water or among each other ( $t$-test, $\mathrm{p}>0.397$ ) (Fig. 1). In contrast, ${ }^{3} \mathrm{H}-\mathrm{TdR}$ 


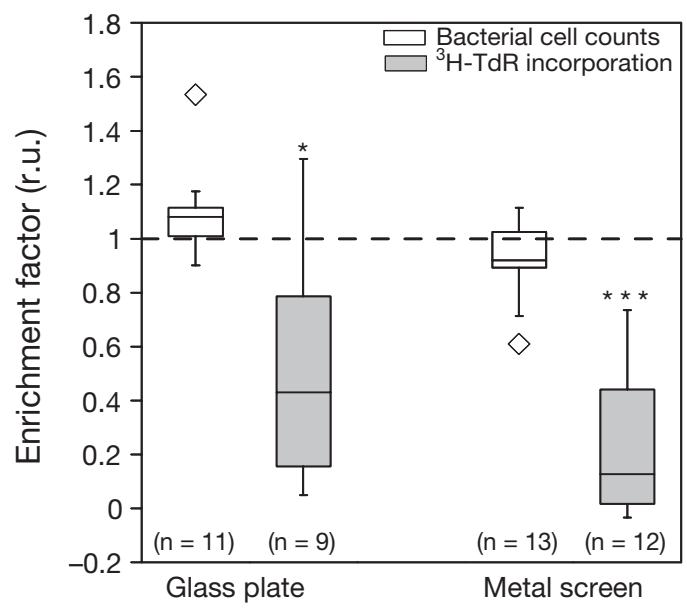

Fig. 1. Sea-surface microlayer samples collected in 2006 with a glass plate and a metal screen. Box-whisker plots show bacterial cell counts and ${ }^{3} \mathrm{H}$-thymidine $\left({ }^{3} \mathrm{H}\right.$-TdR) incorporation of samples obtained with each device compared to the values in the underlying water (Enrichment factor). Dashed line indicates unity of values. Diamonds indicate box-whisker plot outliers, defined as any point falling above the following: upper quartile $-(1.5 \times$ interquartile range $)$. r.u.: relative units Enrichment factor. ${ }^{*} \mathrm{p}<0.05{ }_{i}{ }^{* *} \mathrm{p}<0.001$

incorporation of the bacterioneuston, although highly variable, was significantly lower (20 to $90 \%$ ) than the incorporation measured in bulk water (MS: $\mathrm{p}<0.001$; GP: $\mathrm{p}=0.027$ ) (Fig. 1).

Interestingly, this decrease in ${ }^{3} \mathrm{H}-\mathrm{TdR}$ incorporation was not measured in a $68 \mu \mathrm{m}$-thick SML sample collected at another time point and obtained from the RD sampler (Table 1). Subsequently, MS and GP samples were taken from the same station on the same day. ${ }^{3} \mathrm{H}$ TdR incorporation in the MS sample was reduced by an order of magnitude compared to that in either the RD sample or bulk water (Table 1). This difference was not due to changes in bacterial abundance or community composition. Total bacterial cell counts of SML samples taken with all 3 sampling devices were comparable among each other and with those in underlying bulk water (Table 1). The bacterial community
Table 1. Comparison of different sea-surface microlayer samples and the underlying bulk water from 12 September 2006 showing the layer thickness, bacterial cell counts, and productivity $\left({ }^{3} \mathrm{H}\right.$-thymidine, ${ }^{3} \mathrm{H}-\mathrm{TdR}$, incorporation; $\pm \mathrm{SD}$ from triplicate measurements). nd: not determined

\begin{tabular}{|c|c|c|c|}
\hline $\begin{array}{l}\text { Water } \\
\text { sample }\end{array}$ & $\begin{array}{c}\text { Layer } \\
\text { thickness } \\
\quad(\mu \mathrm{m})\end{array}$ & $\begin{array}{c}\text { Bacterial } \\
\text { cell counts } \\
\left(10^{5} \text { cells ml }{ }^{-1}\right)\end{array}$ & $\begin{array}{l}\text { Bacterial produc- } \\
\text { tivity }\left(\mathrm{pmol}{ }^{3} \mathrm{H}-\right. \\
\left.\operatorname{TdR~}^{-1} \mathrm{l}^{-1}\right)\end{array}$ \\
\hline Bulk water & & 9.22 & $19.02 \pm 2.27$ \\
\hline Glass plate & 27 & 9.07 & nd \\
\hline Rotating drum & 68 & 9.51 & $21.63 \pm 1.92$ \\
\hline Metal screen & 264 & 8.42 & $0.33 \pm 0.35$ \\
\hline
\end{tabular}

composition of these samples, as revealed by $16 \mathrm{~S}$ rDNA fingerprints from the RD and MS samples, was also similar to that in bulk water (Fig. 2). In both the particle-attached and non-attached size fractions, all 3 samples clustered together in Jaccard and Pearson comparisons. However, the similarity values of the non-attached fraction were higher $(>94.9 \%$ in Pearson and $>86.4 \%$ in Jaccard comparisons) than those of the particle-attached fraction $(>81.4 \%$ in Pearson and $>50.6 \%$ in Jaccard comparisons).

\section{Tank experiments}

A possible influence of these samplers was tested in a series of tank experiments. Homogenized seawater sampled with either the GP or the MS device indeed showed a selective reduction in ${ }^{3} \mathrm{H}$-TdR incorporation of 70 to $80 \%$ compared to reference water ( $t$-test, $\mathrm{p}=$ 0.011). In contrast, the total bacterial cell counts of all samples did not differ ( $p>0.713$ ) (Fig. 3A). Additionally, T-RFLP analysis revealed a similar community composition among all samples (Fig. 3B), with each sample showing 30 distinct peaks. Only 5 (out of 90) peaks were solely detected in one of the samples $(2$ peaks in the reference water and in the GP; 1 peak in the MS). Two peaks were not detectable in the refer-
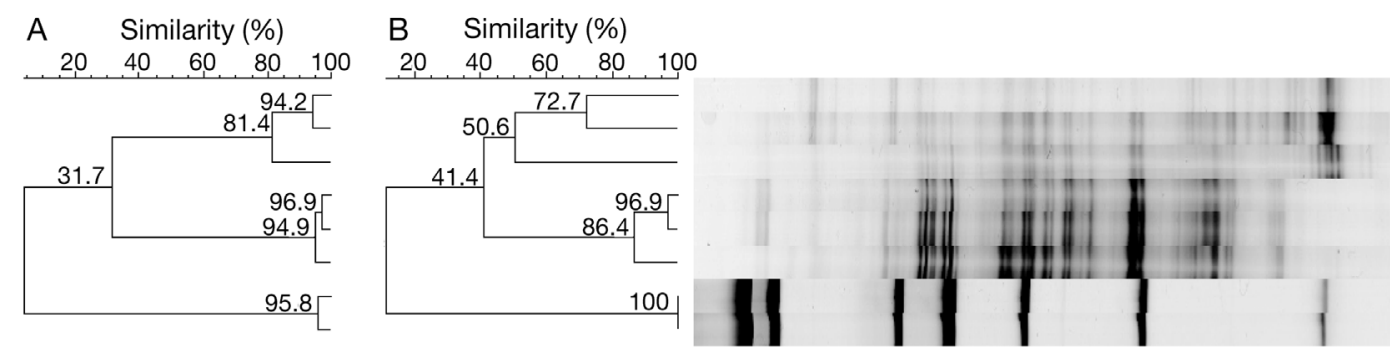

Bulk water $(3 \mu \mathrm{m})$ Rotating drum $(3 \mu \mathrm{m})$ Metal screen $(3 \mu \mathrm{m})$ Bulk water $(0.2 \mu \mathrm{m})$ Rotating drum $(0.2 \mu \mathrm{m})$ Metal screen $(0.2 \mu \mathrm{m})$ Standard Standard

Fig. 2. 16S rDNA fingerprints of sea-surface microlayer samples and of underlying bulk water from 12 September 2006 reveal similar bacterial community compositions in the particle-attached $(3 \mu \mathrm{m})$ and non-attached $(0.2 \mu \mathrm{m})$ fractions. Similarity of the band patterns is shown by (A) Pearson and (B) Jaccard comparisons 


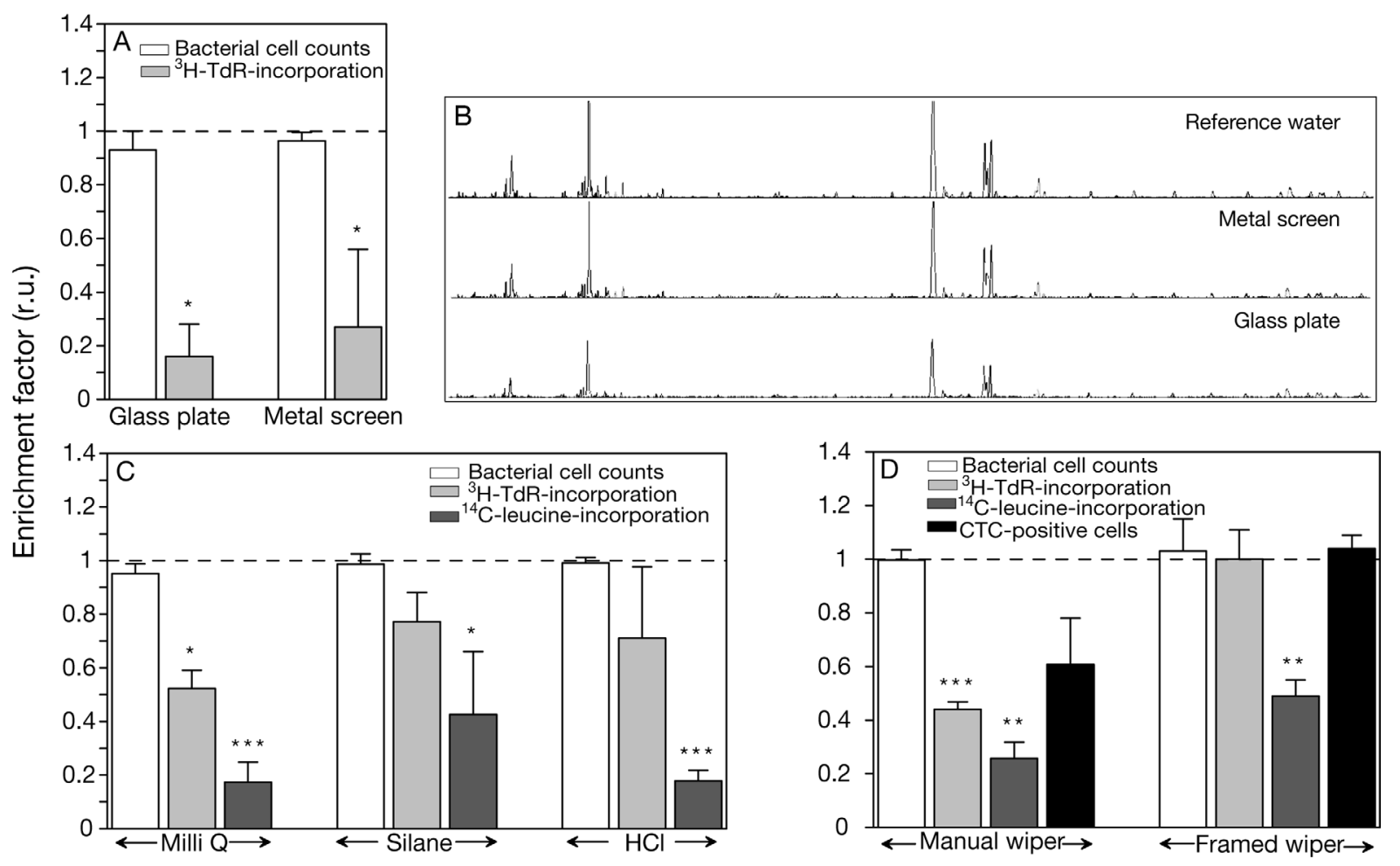

Fig. 3. Results from tank experiments designed to examine the potential bias of sea-surface microlayer sampling devices. (A) Bacterial cell counts and ${ }^{3} \mathrm{H}$-thymidine $\left({ }^{3} \mathrm{H}\right.$-TdR) incorporation $(\mathrm{n}=6)$ as well as $(\mathrm{B})$ bacterial community composition by $16 \mathrm{~S}$ rDNA fingerprints of glass plate (GP) and metal screen samples; (C) effects of different cleaning treatments on bacterial cell counts, ${ }^{3} \mathrm{H}-$ $\mathrm{TdR}$ and ${ }^{14} \mathrm{C}$-leucine incorporation for GP samples $(\mathrm{n}=3)$; (D) results of $2 \mathrm{GP}$ wiping techniques, with subsequent analysis of all parameters including CTC uptake $(\mathrm{n}=3)$. Results from $\mathrm{A}, \mathrm{C}$ and $\mathrm{D}$ are expressed as enrichment factors. Dashed lines indicate unity of values between sea-surface microlayer sampling device and reference water. r.u.: relative units. ${ }^{*} p<0.05 ;{ }^{* *} p<0.01$; ${ }^{* * *} \mathrm{p}<0.001$. Error bars are SD

ence water and MS sample but in the other samples. Only 1 peak was not detectable in the GP sample. Taken together, all similar peaks contributed to more than $93 \%$ of total peak height.

The effect of different GP cleaning procedures on the recovery of ${ }^{3} \mathrm{H}-\mathrm{TdR}$ incorporation was also examined. Neither a Milli-Q water treatment nor treatment with silane or $\mathrm{HCl}$ showed an effect on the reduced ${ }^{3} \mathrm{H}-\mathrm{TdR}$ incorporation (Fig. 3C). However, the high variability in the absolute values of ${ }^{3} \mathrm{H}-\mathrm{TdR}$ incorporation in the control samples most probably retained statistical significance $(0.05<\mathrm{p}<0.376)$. Moreover, ${ }^{14} \mathrm{C}$-leucine incorporation, used as a second parameter for measuring bacterial productivity in the same samples, was reduced to an even greater extent (60 to $80 \%$, p < 0.011).

Finally, 2 different wiping techniques were compared. The first consisted of a manual hand-wiper equipped with a Teflon blade. This device was used in all of the previously described experiments of the present study. The second technique was similar, except that the wiper blades were fixed in a PVC frame in a construction modified from the one described in Hardy et al. (1985) and by T. Reinthaler (pers. comm.).
Although the layer thicknesses in this experiment did not differ between the wiping techniques, it was generally found that the fixed-blade wiper collected thicker SML samples $(48 \pm 6 \mu \mathrm{m})$ than the hand-wiper (32 $\pm 7 \mu \mathrm{m})$ in the 2007 samples (data not shown). This was most likely due to more efficient retrieval of the water sample from the GP because the plate was completely dry after wiping, which was not true for the manual hand-wiper. Surprisingly, the use of this new wiping technique restored ${ }^{3} \mathrm{H}$-TdR incorporation $(\mathrm{p}=$ 0.370) and CTC uptake ( $\mathrm{p}=0.705)$ (Fig. 3D), but ${ }^{14} \mathrm{C}$ leucine incorporation was still reduced by about $50 \%$ $(p=0.009)$. The fixed-blade device had no effect on total bacterial cell counts (Fig. 3D) or community composition (data not shown) compared to the values obtained with the reference water.

\section{SML samples 2007}

The GP combined with the fixed-blade device was found to be the sampling technique with the fewest biases for measurements of bacterial parameters. Thus 
Table 2. Sea-surface microlayer sampling stations in the southern (Warnemuende, WMD) and central Baltic Sea (Gotland Basin, GB). Thickness of the layer of the glass-plate samples, wind speed, and occurrence $(+)$ of slicks are reported for summer 2007. nd: not determined

\begin{tabular}{|lccccc|}
\hline Stn & Date & $\begin{array}{c}\text { Thickness } \\
(\mu \mathrm{m})\end{array}$ & Location & $\begin{array}{c}\text { Wind } \\
\left(\mathrm{m} \mathrm{s}^{-1}\right)\end{array}$ & $\begin{array}{c}\text { Visible } \\
\text { slicks }\end{array}$ \\
\hline 1 & 18 Jun 2007 & 44 & WMD & 0.9 & - \\
2 & 18 Jun 2007 & 38 & WMD & 1.8 & - \\
3 & 19 Jun 2007 & 42 & WMD & 2.8 & - \\
4 & 20 Jun 2007 & 49 & WMD & 5.6 & - \\
5 & 10 Jul 2007 & 54 & GB & 3.5 & - \\
6 & 10 Jul 2007 & 52 & GB & 4 & - \\
7 & 11 Jul 2007 & nd & GB & 3 & + \\
8 & 11 Jul 2007 & 57 & GB & 1.5 & + \\
9 & 14 Jul 2007 & nd & GB & 3.9 & - \\
10 & 07 Aug 2007 & 53 & WMD & 2.3 & + \\
11 & 14 Aug 2007 & 41 & WMD & 1.3 & + \\
\hline
\end{tabular}

it was chosen to collect a further set of SML samples from the southern Baltic Sea (Warnemuende) and the central Baltic Sea (Gotland Basin) in summer 2007 (Table 2). The absolute values of the total bacterial cell counts were comparable in SML and bulk samples ( $\mathrm{p}=$ 0.592) (Fig. 4A). Interestingly, ${ }^{3} \mathrm{H}-\mathrm{TdR}$ incorporation was still reduced by 50 to $80 \%(\mathrm{p}<0.001)$ compared to incorporation in the underlying bulk water (Figs. $4 \mathrm{C}$ $\& 5)$. This was evident throughout the sampling season and was measured in SML samples from the southern as well as the central Baltic Sea (Fig. 4). However, the enumeration of CTC-positive cells showed highly variable but overall comparable absolute and relative cell counts for bacterioplankton and bacterioneuston $(\mathrm{p}=$ 0.710) (Figs. 4B \& 5).

The variability in the number of CTC-positive cells did not correlate with the rates of ${ }^{3} \mathrm{H}-\mathrm{TdR}$ incorpora-

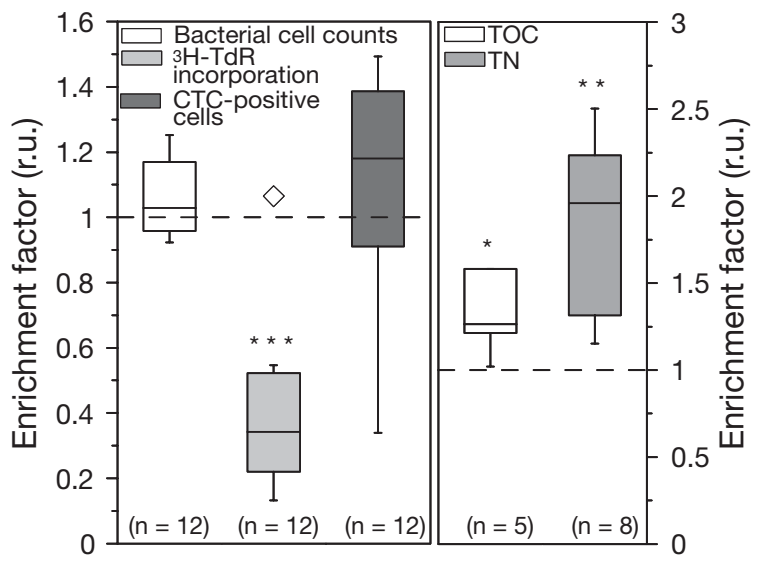

Fig. 5. Relative ratios (enrichment factor) of sea-surface microlayer samples compared to the underlying bulk water, both collected in summer 2007 . Total bacterial cell counts, ${ }^{3} \mathrm{H}-$ thymidine $\left({ }^{3} \mathrm{H}-\mathrm{TdR}\right)$ incorporation, CTC-positive cells, total organic carbon (TOC), and total nitrogen (TN) are shown. See Fig. 1 for explanation of figure

tion for absolute numbers of the SML and the underlying water (data not shown) or the enrichment factors of both parameters (Spearman's rank, $r=0.055, p=0.873$ ) (Fig. 6C). Additionally, the relative uptake of CTC and ${ }^{3} \mathrm{H}-\mathrm{TdR}$ and the variations within did not correlate with the wind speed during sampling (CTC: $\mathrm{r}=-0.045, \mathrm{p}=$ 0.894; ${ }^{3} \mathrm{H}-\mathrm{TdR}: \mathrm{r}=0.364, \mathrm{p}=0.272$ ) (Fig. 6A,B), which is known to change the properties of the SML. Wind speed also did not correlate with either TOC or TN accumulation (data not shown); both of which were always enriched when measured. The accumulation of TN ( 25 to $125 \%, p=0.002$ ) was more pronounced than the accumulation of TOC (25 to $50 \%, p=0.028)$ (Fig. 5).
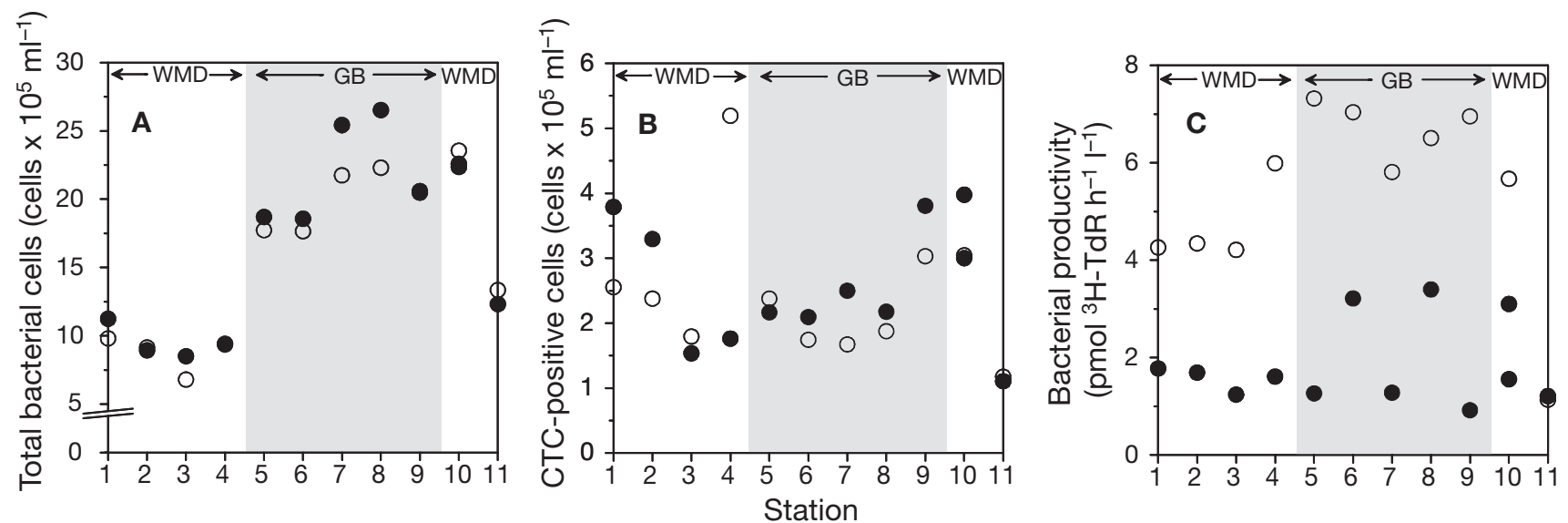

Fig. 4. Comparison of absolute values for (A) total bacterial cell counts, (B) CTC-positive cells, and (C) ${ }^{3} \mathrm{H}$-thymidine $\left({ }^{3} \mathrm{H}-\mathrm{TdR}\right)$ incorporation in sea-surface microlayer samples (•) and the underlying bulk water (O). Samples were collected in summer 2007 in the southern (Warnemuende, WMD) and central Baltic Sea (Gotland Basin, GB; gray shading). For detailed station information, see Table 2 

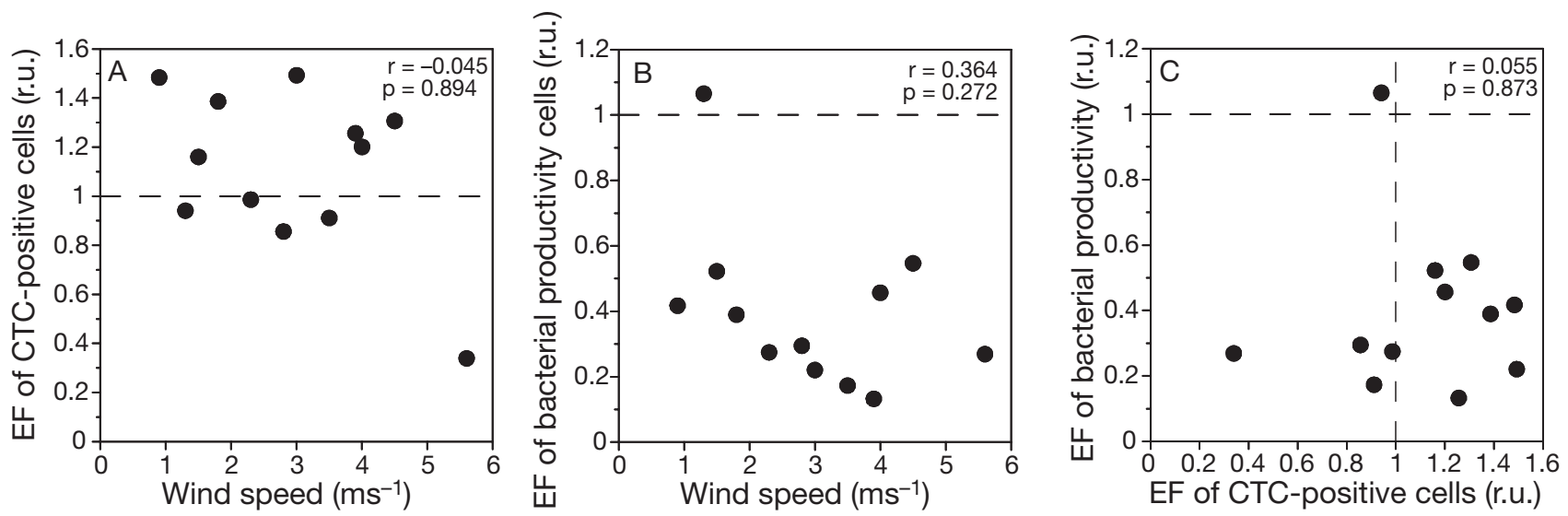

Fig. 6. Relationship between the relative ratios (enrichment factor, EF) of (A) CTC-positive cells and (B) ${ }^{3} \mathrm{H}$-thymidine incorporation and wind speed during sampling. (C) Relationship between the relative ratios (EF) of both activity parameters. Dashed lines indicate unity of values between the sea-surface microlayer and the underlying water, i.e. $\mathrm{EF}=1$. r.u.: relative units

\section{DISCUSSION}

The SML is known to influence exchange processes between the atmosphere and water bodies by physicochemical processes, e.g. the dampening of capillary waves induced by surface-active substances (Frew 1997). It has long been suggested that bacteria within the SML (bacterioneuston) play a pivotal role in these exchange processes. However, determining whether the bacterioneuston is 'successful' (Maki 1993) remains controversial, with previous studies reporting conflicting results regarding bacterioneuston activity, abundance, and diversity compared to bacterioplankton.

\section{Critical evaluation of SML sampling techniques}

The application of SML sampling techniques must take into account the thickness of the sampled SML and the mode of operation of the chosen sampling device, especially its degree of selectivity. Astonishingly, and as pointed out by others, only a few studies have examined the potential bias of sampling devices with respect to biological parameters (Hatcher \& Parker 1974, Agogué et al. 2004, Franklin et al. 2005). In one such study, which extensively examined the possible bias of MS- and GP-type samplers, no selective effects were found for most of the bacterial parameters studied (Agogué et al. 2004).

In light of those observations, ${ }^{3} \mathrm{H}$-TdR incorporation in different SML samples of the southern Baltic Sea was measured. Variable but overall reduced ${ }^{3} \mathrm{H}-\mathrm{TdR}$ incorporation was measured in GP and MS samples compared to incorporation in the underlying water; this was in contrast to the unchanged incorporation measured on one occasion in an RD sample, where MS and RD samples were taken simultaneously at the same station. Assuming that the SMLs of the MS and RD samples were identical except for the thickness of the collected layer, these results are surprising since inhibitory factors should have had a more pronounced effect on the RD samples because of less dilution with bulk water. This discrepancy was examined in tank experiments with the GP and MS samples; the results showed a strong reduction of ${ }^{3} \mathrm{H}-\mathrm{TdR}$ incorporation in samples obtained with either device compared to the incorporation measured in reference water. A selective reduction of bacterial productivity has not been reported before, although productivity measurements in another tank experiment involving GP and MS samplers were quite variable (Agogué et al. 2004).

Sampling devices differ in their mode of operation and in the material of the sampler itself (Huehnerfuss 1981). Based on the results of the present study, we conclude that the modes of operation of GP and MS devices are most likely not selective, because bacterial abundance and community composition, based on $16 \mathrm{~S}$ rDNA fingerprints, were comparable to the reference water in all experiments. Adsorption of bacteria to the GP might stress the cells, reflected in a reduction of bacterial productivity, but a similarly pronounced reduction occurred in samples collected with the MS, in which the water is simply trapped within the mesh of the screen.

Another reason for the observed reduction in bacterial productivity might have been the presence of inhibitory substances originating from the sampling devices themselves. Most authors of previous research either did not mention how or if their sampling devices were treated, or reported treatment of the GP with Milli-Q water and ethanol (Agogué et al. 2004), HCL (Reinthaler et al. 2008), or silane (Gever et al. 1996). 
We tested these different treatments, none of which had an effect on the reduced ${ }^{3} \mathrm{H}$-TdR incorporation. Furthermore, in all treatments the rate of ${ }^{14} \mathrm{C}$-leucine incorporation was reduced.

Ultimately, we developed a sampling technique using a different wiping mechanism that restored ${ }^{3} \mathrm{H}$ TdR incorporation and CTC uptake. One possible, but highly speculative, reason for the success of this method is that it increased the speed of sampling, which was twice as fast as that of the framed-wiper technique and thus reduced the time between sampling and the start of the incubations. However, ${ }^{14} \mathrm{C}$ leucine incorporation in our experiments was still reduced, which might have been caused by isotope dilution due to higher leucine concentrations in the GP samples. In our experiments, we did not measure amino acid concentrations, but they have been shown to be enriched in the SML (Kuznetsova et al. 2004) and considered as external dilution factors in productivity rates of the bacterioneuston (Reinthaler et al. 2008). Although the water was homogenized prior to sampling, the rapid accumulation especially of hydrophobic amino acids might have occurred. While there is no satisfactory explanation for the persistent decrease in ${ }^{14} \mathrm{C}$-leucine incorporation, it suggests that bacterial activity parameters are unequally affected by SML sampling devices. Furthermore, ${ }^{3} \mathrm{H}$-TdR incorporation was found to be the suitable method to measure bacterioneuston productivity with our sampling device.

\section{Interpretation of SML samples 2007}

During our studies in the Baltic Sea, bacterial cell counts did not differ between SML samples and the underlying bulk water. Absolute cell numbers were consistent with those previously reported for the surface waters of the southern and central Baltic Sea (Heinänen 1991, Schumann et al. 2003). An enrichment of colony-forming units in some SML samples from the western Swedish coast has also been reported (Hermansson et al. 1987). However, to the best of our knowledge, cultivation-independent bacterial cell numbers in SML samples from the Baltic Sea have, until now, not been published.

The abundance of CTC-positive cells in our SML samples was highly variable but overall similar to that of the underlying water. This was evident for absolute cell counts and relative values (8 to $37 \%$ ) compared to total bacterial cells. Additionally, flow cytometric analysis of samples of the SML and the underlying water showed a similar abundance of bacterial cells with a high nucleic acid content (data not shown), which are thought to represent the active part of the bacterial community (Gasol et al. 1999).
These results imply that an active bacterioneuston community exists. The SML is thought to reflect conditions favourable to heterotrophic bacteria (Sieburth et al. 1976) due to the accumulation of organic and inorganic substrates (Hardy et al. 1997). Enriched concentrations of TOC have been found to correlate with increased community respiration in the SML compared to the underlying bulk water (Obernosterer et al. 2005). Elevated substrate supply might also explain enhanced enzymatic activities of the bacterioneuston in different aquatic systems (Münster et al. 1997, Kuznetsova \& Lee 2001). However, several authors have reported highly variable or no significant changes of bacterial productivity in the SML (Joux et al. 2006, Reinthaler et al. 2008), or even a decrease compared to the underlying bulk water (Obernosterer et al. 2008), although in all studies organic matter has been found to be enriched in the SML.

In the present study we also detected an accumulation of TOC and TN in the SML of the Baltic Sea. The enrichment of TN was more pronounced, in agreement with a recent report in which dissolved organic nitrogen (DON) was more enriched than dissolved organic carbon (DOC) (Reinthaler et al. 2008). Due to sample volume limitations, we were only able to determine total organic material (TOM) and therefore could not differentiate between the dissolved and the particulate fraction. A recent study found a constant accumulation of particulate organic carbon (POC) but not DOC in nylon screen samples (Obernosterer et al. 2008), a result consistent with previous reports which concluded that enrichments for dissolved matter are not as pronounced as those for the respective particulate material (Hunter 1997). However, this is not a common feature, as the TOC in SML samples obtained with a GP as well as in the underlying water, has been found to contain similar high ratios of DOC (Reinthaler et al. 2008).

The enrichment of TOM in our samples apparently did not fuel bacterial activity. Instead, there was an overall reduction in the incorporation of ${ }^{3} \mathrm{H}-\mathrm{TdR}$ in SML samples collected from different stations during the summer of 2007, suggesting that DNA synthesis and thus cytokinetic activities were generally impaired. However, one recent study to use ${ }^{3} \mathrm{H}-\mathrm{TdR}$ as a measurement for bacterial production in SML samples obtained from a GP showed that incorporation was highly variable but overall not significantly changed compared to incorporation in the underlying water (Agogué et al. 2004). Diverse factors seem to influence the relationship between substrate supply and bacterial productivity in the SML. Variable ${ }^{3} \mathrm{H}-\mathrm{TdR}$ incorporation has been discussed to be affected by diel cycles, with increasing uptake during the night, although overall incorporation was still found to be consistently 
lower compared to the underlying water (Carlucci et al. 1986). This might result from the inability of the bacterioneuston to take up the rich pool of nutrients during high UV exposure, as reported for bacterioplankton (Herndl et al. 1993), perhaps due to direct (DNA damage) or indirect (photochemical alteration of substrate) effects. Yet these diel patterns do not always explain the variable productivity of the bacterioneuston, e.g. they might be masked by wind influences (Reinthaler et al. 2008).

Wind speed influences the properties of the SML. A recent study found that decreasing leucine incorporation by the bacterioneuston was correlated to low wind speeds (Obernosterer et al. 2008). In our experiments, however, the observed activity patterns did not correlate with the actual wind speed during sampling or with the wind history, defined as the mean wind speed up to $6 \mathrm{~h}$ prior to sampling (data not shown). Furthermore, we found no correlation between CTC uptake and ${ }^{3} \mathrm{H}$-TdR incorporation in the SML samples. Therefore, it seems that the bacterioneuston community remains metabolically active but does not proliferate as intensely as the bacterioplankton. This activity pattern was found in SML samples from coastal and open water samples as well as those in slick and non-slick samples.

Taken together, our data show that, despite the accumulation of TOM in the SML, bacterioneuston productivity is not enhanced. Rather, although the abundance of active cells is comparable to that in the underlying water, certain cellular activities, e.g. cytokinesis, are impaired.

\section{CONCLUSIONS}

There is an essential need to compare data from different studies in order to better characterize the bacterioneuston and to gain detailed insights into its structure and function. However, reliable comparisons of such data were thought to be impossible due to the different modes of operation of the various sampling devices (Carlson 1982). Some other authors have suggested that only SML samples taken with the same type of sampling device can be compared (Van Vleet \& Williams 1980). However, the present study shows that comparisons should be made carefully, and the results underline previous recommendations concerning the need to evaluate the sampling devices (Agogué et al. 2004).

Our in situ results support the view of the SML as a demanding, even stressful habitat (Dietz et al. 1976). Furthermore, the presence of a specifically adapted bacterial community in the SML is unlikely. Future studies should be aimed at specifying the factors influ- encing bacterioneuston activity. For this purpose, characterizations of the effects of different physicochemical parameters at the community and single-cell levels are essential.

Acknowledgements. The technical assistance of H. Brockmöller and A. Grüttmüller during the molecular work and flow cytometric analysis, respectively, was very much appreciated. The captain and crew of the RV 'Professor Albrecht Penck' as well as U. Hehl and R. Kay had an important part in our ability to successfully sample the sea-surface microlayer. This study was supported by the Leibniz Society (WGL-Pakt project FILGAS) and the Federal Ministry of Education and Research (SOPRAN, FKZ: 03F0462B). We thank 3 anonymous reviewers for helpful comments.

\section{LITERATURE CITED}

Agogué H, Casamayor EO, Joux F, Obernosterer I and others (2004) Comparison of samplers for the biological characterization of the sea surface microlayer. Limnol Oceanogr Methods 2:213-225

Agogué H, Casamayor EO, Bourrain M, Obernosterer I, Joux F, Herndl GJ, Lebaron P (2005) A survey on bacteria inhabiting the sea surface microlayer of coastal ecosystems. FEMS Microbiol Ecol 54:269-280

Auguet JC, Casamayor EO (2008) A hotspot for cold crenarchaeota in the neuston of high mountain lakes. Environ Microbiol 10:1080-1086

Carlson DJ (1982) A field evaluation of plate and screen microlayer sampling techniques. Mar Chem 11:189-208

Carlucci AF, Craven DB, Robertson KJ, Williams PM (1986) Surface-film microbial populations: diel amino acid metabolism, carbon utilization, and growth rates. Mar Biol 92:289-297

> Chin-Leo G, Kirchman DL (1988) Estimating bacterial production in marine waters from the simultaneous incorporation of thymidine and leucine. Appl Environ Microbiol 54:1934-1939

> Cunliffe M, Schafer H, Harrison E, Cleave S, Upstill-Goddard R, Murrell JC (2008) Phylogenetic and functional gene analysis of the bacterial and archaeal communities associated with the surface microlayer of an estuary. ISME J 2: $776-789$

> Dietz AS, Albright LJ, Tuominen T (1976) Heterotrophic activities of bacterioneuston and bacterioplankton. Can J Microbiol 22:1699-1709

Dunbar J, Ticknor LO, Kuske CR (2001) Phylogenetic specificity and reproducibility and new method for analysis of terminal restriction fragment profiles of 16S rRNA genes from bacterial communities. Appl Environ Microbiol 67: 190-197

Falkowska L (1999a) Sea surface microlayer: a field evaluation of teflon plate, glass plate and screen sampling techniques. Part 1. Thickness of microlayer samples and relation to wind speed. Oceanologia 41:211-221

Falkowska L (1999b) Sea surface microlayer: a field evaluation of Teflon plate, glass plate and screen sampling techniques. Part 2. Dissolved and suspended matter. Oceanologia 41:223-240

> Franklin MP, McDonald IR, Bourne DG, Owens NJP, UpstillGoddard RC, Murrell JC (2005) Bacterial diversity in the bacterioneuston (sea surface microlayer): the bacterioneuston through the looking glass. Environ Microbiol 7: 
$723-736$

Frew NM (1997) The role of organic films in air-sea gas exchange. In: Liss PS, Duce RA (eds) The sea-surface and global change. Cambridge University Press, Cambridge, p 121-172

Garrett WD (1965) Collection of slick-forming material from the sea-surface. Limnol Oceanogr 10:602-605

Garrett WD, Duce RA (1980) Surface microlayer samplers. In: Dobson F, Hasse L, Davis R (eds) Air-sea interaction. Plenum, New York, p 471-490

Gasol JM, Zweifel UL, Peters F, Fuhrman JA, Hagström ^̊ (1999) Significance of size and nucleic acid content heterogeneity as measured by flow cytometry in natural planktonic bacteria. Appl Environ Microbiol 65: $4475-4483$

Gever JR, Mabury SA, Crosby DG (1996) Rice field surface microlayers: collection, composition and pesticide enrichment. Environ Toxicol Chem 15:1676-1682

Hannig M, Braker G, Dippner J, Jürgens K (2006) Linking denitrifier community structure and prevalent biogeochemical parameters in the pelagial of the central Baltic Proper (Baltic Sea). FEMS Microbiol Ecol 57:260-271

Hardy JT (1982) The sea surface microlayer: biology, chemistry and anthropogenic enrichment. Prog Oceanogr 11: 307-328

Hardy JT, Cleary J (1992) Surface microlayer contamination and toxicity in the German Bight. Mar Ecol Prog Ser 91: 203-210

Hardy JT, Apts CW, Crecelius EA, Bloom NS (1985) Sea-surface microlayer metals enrichments in an urban and rural bay. Estuar Coast Shelf Sci 20:299-312

Hardy JT, Hunter KA, Calmet D, Cleary JJ and others (1997) Biological effects of chemical and radiative change in the sea surface. In: Liss PS, Duce RA (eds) The sea surface and global change. Cambridge University Press, Cambridge, $p$ 35-70

Harvey RW (1966) Microlayer collection from the sea surface: a new method and initial results. Limnol Oceanogr 11: 608-613

Harvey RW, Burzell LA (1972) A simple microlayer method for small samples. Limnol Oceanogr 17:156-157

Hatcher RF, Parker BC (1974) Laboratory comparison of four surface microlayer samplers. Limnol Oceanogr 19: 162-165

> Heinänen AP (1991) Baterial numbers, biomass and productivity in the Baltic Sea: a cruise study. Mar Ecol Prog Ser 70:283-290

> Hermansson M, Dahlbaeck B (1983) Bacterial activity at the air/water interface. Microb Ecol 9:317-328

> Hermansson M, Jones GW, Kjelleberg S (1987) Frequency of antibiotic and heavy metal resistance, pigmentation, and plasmids in bacteria of the marine air-water interface. Appl Environ Microbiol 53:2338-2342

Herndl GJ, Mullerniklas G, Frick J (1993) Major role of ultraviolet-B in controlling bacterioplankton growth in the surface layer of the ocean. Nature 361:717-719

Huehnerfuss $H$ (1981) On the problem of sea surface film sampling: a comparison of 21 microlayer-, 2 multilayer-, and 4 selected subsurface-samplers. Part 1. Sonderdr Meerestechnik 12:137-142

Hunter KA (1997) Chemistry of the sea-surface microlayer. In: Liss PS, Duce RA (eds) The sea surface and global change. Cambridge University Press, Cambridge, p 287-320

> Joux F, Agogué H, Obernosterer I, Dupuy C, Reinthaler T, Herndl GJ, Lebaron P (2006) Microbial community structure in the sea surface microlayer at two contrasting coastal sites in the northwestern Mediterranean Sea.
Aquat Microb Ecol 42:91-104

Kuznetsova M, Lee C (2001) Enhanced extracellular enzymatic peptide hydrolysis in the sea-surface microlayer. Mar Chem 73:319-332

- Kuznetsova M, Lee C (2002) Dissolved free and combined amino acids in nearshore seawater, sea surface microlayers and foams: influence of extracellular hydrolysis. Aquat Sci 64:252-268

Kuznetsova M, Lee C, Aller J, Frew N (2004) Enrichment of amino acids in the sea surface microlayer at coastal and open ocean sites in the North Atlantic Ocean. Limnol Oceanogr 49:1605-1619

> Labrenz M, Jost G, Jürgens K (2007) Distribution of abundant prokaryotic organisms in the water column of the central Baltic Sea with an oxic-anoxic interface. Aquat Microb Ecol 46:177-190

Lehours AC, Bardot C, Thenot A, Debroas D, Fonty G (2005) Anaerobic microbial communities in Lake Pavin, a unique meromictic lake in France. Appl Environ Microbiol 71: 7389-7400

> Liu WT, Marsh TL, Cheng H, Forney LJ (1997) Characterization of microbial diversity by determining terminal restriction fragment length polymorphisms of genes encoding 16S rRNA. Appl Environ Microbiol 63:4516-4522

Maki JS (1993) The air-water interface as an extreme environment. In: Ford TE (ed) Aquatic microbiology: an ecological approach. Blackwell Scientific Publications, Boston, MA, p 409-439

Maki JS (2002) Neuston microbiology: life at the air-water interface. In: Bitton G (ed) The encyclopedia of environmental microbiology, Vol 4. John Wiley, New York, p 2133-2144

Münster U, Heikkinen E, Knulst J (1997) Nutrient composition, microbial biomass and activity at the air-water interface of small boreal forest lakes. Hydrobiologia 363: 261-270

Norkrans B (1980) Surface microlayers in aquatic environments. Adv Microb Ecol 4:51-85

> Obernosterer I, Catala P, Reinthaler T, Herndl GJ, Lebaron P (2005) Enhanced heterotrophic activity in the surface microlayer of the Mediterranean Sea. Aquat Microb Ecol 39:293-302

Obernosterer I, Catala P, Lami R, Caparros J and others (2008) Biochemical characteristics and bacterial community structure of the sea surface microlayer in the South Pacific Ocean. Biogeosciences 5:693-705

Reinthaler T, Sintes E, Herndl GJ (2008) Dissolved organic matter and bacterial production and respiration in the seasurface microlayer of the open Atlantic and the western Mediterranean Sea. Limnol Oceanogr 53:122-136

Schumann R, Rieling T, Görs S, Hammer A, Selig U, Schiewer U (2003) Viability of bacteria from different aquatic habitats. I. Environmental conditions and productivity. Aquat Microb Ecol 32:121-135

Schwieger F, Tebbe CC (1998) A new approach to utilize PCR-single-strand-conformation polymorphism for $16 \mathrm{~S}$ rRNA gene-based microbial community analysis. Appl Environ Microbiol 64:4870-4876

Sieburth JM (1983) Microbiological and organic-chemical processes in surface and mixed layers. In: Liss PS, Slinn WGN (eds) Air-sea exchange of gases and particles. D. Reidel, Hingham, p 121-172

> Sieburth JMN, Willis PJ, Johnson KM, Burney CM and others (1976) Dissolved organic matter and heterotrophic microneuston in the surface microlayers of the North Atlantic. Science 194:1415-1418

van Vleet ES, Williams PM (1980) Sampling sea surface films: 
a laboratory evaluation of techniques and collecting materials. Limnol Oceanogr 25:764-770

Weinbauer MG, Fritz I, Wenderoth DF, Höfle MG (2002) Simultaneous extraction from bacterioplankton of total RNA and DNA suitable for quantitative structure and function analyses. Appl Environ Microbiol 68:1082-1087

Editorial responsibility: Gerhard Herndl, Vienna, Austria
Williams PM (1986) Chemical and microbiological studies of sea-surface films in the southern Gulf of California and off the west coast of Baja California. Mar Chem 19:17-98

Wurl O, Obbard JP (2004) A review of pollutants in the seasurface microlayer (SML): a unique habitat for marine organisms. Mar Pollut Bull 48:1016-1030

Submitted: January 23, 2009; Accepted: July 8, 2009

Proofs received from author(s): October 30, 2009 